\title{
$\square$ Diastolic function in patients with hypertrophic cardiomyopathy and left ventricle outflow tract obstruction after alcohol septal ablation
}

\section{Irena Ivanac \\ Vranešić* \\ Karlo Golubić \\ Eduard Margetić \\ Petra Angebrandt \\ Vojtjeh Brida \\ Anton Šmalcelj \\ University of Zagreb \\ School of Medicine \\ University Hospital Centre \\ Zagreb, Zagreb, Croatia}

RECEIVED:

April 15, 2015

ACCEPTED:

April 20, 2015
KEYWORDS: hypertrophic cardiomyopathy, left ventricle outflow tract obstruction, alcohol septal ablation, diastolic function, left atrial volume.

CITATION: Cardiol Croat. 2015;10(3-4):61. | DOI: http://dx.doi.org/10.15836/ccar.2015.61

ORCID: Irena Ivanac Vranešić, http://orcid.org/0000-0002-6910-9720 • Karlo Golubić, http://orcid.org/0000-0003-0684-6333 - Eduard Margetić, http://orcid.org/0000-0001-9224-363X • Petra Angebrandt, http://orcid.org/0000-0001-5431-9736 • Vojtjeh Brida, http://orcid.org/0000-0002-8191-3615 • Anton Šmalcelj, http://orcid.org/0000-0002-4497-542X

*ADDRESS FOR CORRESPONDENCE: Irena Ivanac Vranešić, Klinički bolnički centar Zagreb, Kišpatićeva 12, HR-10000 Zagreb, Croatia. Phone: +385-91-505-9303. E-mail: irena.ivanac@gmail.com

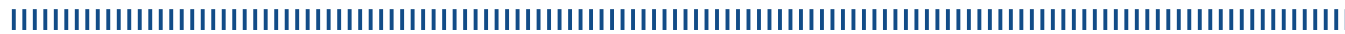

INTRODUCTION: Alcohol septal ablation (ASA) is established treatment method for symptomatic patients with hypertrophic cardiomyopathy (HCM) and left ventricle outflow tract (LVOT) obstruction who do not respond to medical treatment. LV diastolic dysfunction is one of the causes of the symptoms in these patients and also of the left atrial (LA) enlargement.1. ${ }^{1-3}$ Since LA size provides important prognostic implications, we wanted to evaluate impact of SAA on diastolic function and LA size and function.

METHODS AND RESULTS: We analyzed retrospectively echocardiography exams of 18 HCM patients with LVOT obstruction who were treated with SAA in period from 2010 to 2014. Only data from 10 patients (age 57 (50-58) years, 7 men) who were in sinus rhythm and had complete echocardiography exams before and 355 (69-459) days after successful SAA were included in our study. LVOT gradient significantly decreased from 76 (70-87) $\mathrm{mmHg}$ to 15 (11-30) $\mathrm{mmHg}, \mathrm{p}=0.0007$. Several parameters of diastolic function ( $E$ and A wave velocity, E/A, deceleration time isovolumic relaxation time, A wave duration, E/E') as well as left atrial end-systolic area, volumes and ejection fraction were studied. We found no significant changes in these parameters after successful ASA.

CONCLUSION: We found no significant changes in echocardiographic diastolic function or LA size and function parameters in our small group of patients with HCM and LVOT obstruction after successful ASA. Larger studies are needed to evaluate these parameters in this patient population.
LITERATURE IIIIIIIIIIIIIIIIIIIIIIIIIIIIIIIIIIIIIIIIIIIIIIIIIIIIIIIIIIIIIIIIIIIIIIIIIIIIIIIIIIIIIIIIIIIIIIIIIIIIIII

1. Authors/Task Force members, Elliott PM, Anastasakis A, Borger MA, Borggrefe M, Cecchi F, et al. 2014 ESC Guidelines on diagnosis and management of hypertrophic cardiomyopathy: the Task Force for the Diagnosis and Management of Hypertrophic Cardiomyopathy of the European Society of Cardiology (ESC). Eur Heart J. 2014;35(39):2733-79. DOI: http://dx.doi.org/10.1093/eurheartj/ehu284.

2. Guttmann OP, Rahman MS, O'Mahony C, Anastasakis A, Elliott PM. Atrial fibrillation and thromboembolism in patients with hypertrophic cardiomyopathy: systematic review. Heart. 2014;100(6):465-72. DOI: http://dx.doi.org/10.1136/heartjnl-2013-304276

3. O'Mahony C, Jichi F, Pavlou M, Monserrat L, Anastasakis A, Rapezzi C, et al; Hypertrophic Cardiomyopathy Outcomes Investigators. A novel clinical risk prediction model for sudden cardiac death in hypertrophic cardiomyopathy (HCM Risk-SCD). Eur Heart J. 2014:35(30):2010-20. DOI: http://dx.doi.org/10.1093/eurheartj/eht439 